\title{
Conceptual ecological models for the Long Island pitch pine barrens: implications for managing rare plant communities
}

\author{
Marilyn J. Jordan ${ }^{\mathrm{a}, *}$, William A. Patterson III $^{\mathrm{b}}$, Andrew G. Windisch ${ }^{\mathrm{c}}$ \\ ${ }^{\mathrm{a}}$ The Nature Conservancy, 250 Lawrence Hill Rd., Cold Spring Harbor, NY 11724, USA \\ ${ }^{\mathrm{b}}$ Department of Natural Resources Conservation, University of Massachusetts, Amherst, MA 01003, USA \\ ${ }^{\mathrm{c}}$ Department of Environmental Protection, Division of Parks \& Forestry, Office of Natural Lands Management, \\ P.O. Box 404, Trenton, NJ 08625-0404, USA
}

\begin{abstract}
Fire dependent pitch pine (Pinus rigida Mill.) and scrub oak (Quercus ilicifolia Wang.) barrens are found on coarse-textured, droughty soils in the northeastern United States. These communities are globablly rare and, in many areas, dependent on active management to sustain them. We used historic and recent aerial photographs of the Central Pine Barrens in New York to develop transition matrices and trajectories of vegetation change. A vegetation map for 1990 provided pre-burn cover type information for a 1,200 ha area burned by an extremely severe wildfire in August 1995. Geographic information system analyses, a firehistory study, post-wildfire research and existing literature provided additional information for development of three conceptual models that describe our understanding of vegetation change in response to fire and land clearing. A simulation model was then used to predict the amount of each cover type in 2046. The reasonableness of the prediction was assessed based on our understanding of pine barrens vegetation dynamics.

In 1938, following a period of frequent, intense wildfires of the region, $90 \%$ of vegetation in the study area was open canopy barrens (including dwarf pine plains, pitch pine-scrub oak woodland, heath, pine-heath woodland, and scrub oak shrubland). Between 1938 and 1994, wildfires decreased in size, the average area burned per year generally declined, and there were no fires in $70 \%$ of the study area. As a result, barrens decreased to $\sim 45 \%$ of study area vegetation. In August 1995, an unusually severe summer wildfire converted 810 ha of woodland and forest into scrub oak shrubland, and increased barrens to $60 \%$ of study area vegetation. Most areas of heath and pine-heath, which comprised 24\% of barrens vegetation in 1996, are successional types that developed on formerly cleared land. In the absence of extensive burning, we expect barrens vegetation to be converted to closedcanopy forest as coppice trees and new seedlings mature. Recent changes in fire regimes are likely to result in a loss of barrens vegetation that exceeds predictions of the simulation model. Careful use of prescribed fire and/or mechanical treatments to simulate the effects of fire are recommended for future restoration and maintenance of pitch pine barrens, and for protection of human life and property.
\end{abstract}

(C) 2003 Elsevier B.V. All rights reserved.

Keywords: Conceptual model; Pitch pine barrens; Scrub oak; Wildfire; Prescribed fire; Fire return interval; Succession; Disturbance; Life histories; Long Island; NY

\section{Introduction}

\footnotetext{
* Corresponding author. Tel.: +1-631-367-3384x121; fax: +1-631-367-4715.

E-mail address: mjordan@tnc.org (M.J. Jordan).
}

Pitch pine (Pinus rigida Mill.) barrens in northeastern North America include woodlands and shrublands with an open tree canopy (10-60\% cover) of 
pitch pine and a dense understory of scrub oak (Quercus ilicifolia Wang.), black huckleberry (Gaylussacia baccata (Wang) Koch), low blueberry (Vaccinium pallidum Ait.), and lowbush blueberry (Vaccinium angustifolium Ait.) (Table 1). Common groundcover plants include golden heather (Hudsonia ericoides L.), bearberry (Arctostaphylos uva-ursi L.), and wintergreen (Gaultheria procumbens L.). Herbaceous species are few and include Pennsylvania sedge (Carex pensylvanica Lam.), bracken fern (Pteridium aquilinum L.), low growing panic grasses (Panicum spp.), joint weed (Polygonella articulata (L.) Meisn.), and cow-wheat (Melampyrum lineare Desr.). In the absence of frequent fire, frost damage, insect herbivory, cutting, or other disturbance, trees invade and barrens convert to closed-canopy forest (Forman, 1979; Little, 1979; Schweitzer and Rawinski, 1988; Thompson, 1995; Kurczewski and Boyle, 2000; Motzkin et al., 2002). Barrens support a suite of state and globally rare Lepidoptera (moths and butterflies) that are dependent on barrens for specific host plants (Schweitzer and Rawinski, 1988; NYNHP, 2002a; Wagner et al., 2003).
About half of the historically known barrens have been lost due to development and prolonged fire suppression (Noss et al., 1995). Restoration and preservation of the ecological integrity of pine barrens, and protection of human health and safety, depend upon fire management practices which include prescribed fire and ecologically sensitive wildfire control. The Long Island (LI) Central Pine Barrens Joint Planning and Policy Commission (CPBJPPC, 1995), governmental agencies, volunteer fire departments and The Nature Conservancy are developing a fire management plan for the Long Island pine barrens. Management recommended by the plan must be based on an understanding of pine barrens ecology if the goal of preserving intact and functional pine barrens communities and species in perpetuity is to be met.

In this paper, we present a set of three conceptual ecological models that synthesize our understanding of the role of fire and historic land clearing in creating and maintaining pine barrens. These models are predictive in a conceptual (not mathematical) sense, and are intended to provide guidance for future prescribed and wild fire management. A simulation model was

Table 1

Cover types used for mapping vegetation in the study area within the Central Pine Barrens, Long Island, New York

\begin{tabular}{lllll}
\hline Cover type $^{\mathrm{a}}$ & $\begin{array}{l}\text { Height of mature } \\
\text { pitch pines }(\mathrm{m})\end{array}$ & $\begin{array}{l}\text { Tree canopy } \\
\text { cover }(\%)\end{array}$ & $\begin{array}{l}\text { Tree species } \\
\text { composition }{ }^{\mathrm{b}}(\%)\end{array}$ & Dominant shrub species $^{\mathrm{b}}$ \\
\hline SO & Variable & $<10$ & Variable & $\begin{array}{l}\text { Scrub oak, huckleberry, blueberry } \\
\text { Scrub oak, huckleberry, blueberry }\end{array}$ \\
DPP & $\leq 4$ & $10-100$ & Pine $=100$ & Scrub oak, huckleberry, blueberry \\
PPSOW & $>4$ & $10-60$ & Pine $>90$ & Golden heather, bearberry \\
PPHW & $>4$ & $10-60$ & Pine $>90$ & Golden heather, bearberry \\
HE $+\mathrm{S}$ & Variable & $<10$ & Pine $>90$ & Scrub oak, huckleberry, blueberry \\
PPOF & $>4$ & Pine $10-90$ & Huckleberry, blueberry \\
COF & $>4$ & Oaks $90-10$ & Pine $\leq 10$ &
\end{tabular}

${ }^{a}$ Barrens types: SO: scrub oak shrubland, variant of PPOHW (NYNHP, 2002b), Bear Oak-Dwarf Chinquapin Oak shrubland (CEGL006111) (NatureServe, 2003). DPP: Dwarf Pine Plains (NYNHP, 2002b), pitch pine-bear oak/kinikinnick shrubland, northern dwarf pine plains (CEGL006097) (NatureServe, 2003). PPSOW: Pitch Pine-Scrub Oak Woodland, Pitch Pine-Oak-Heath Woodland (NYNHP, 2002b), Pitch Pine-Scrub Oak Barrens (Finton, 1998), in part Pitch Pine-Scrub Oak-roundhead bushclover woodland (CEGL006025 ECS) (NatureServe, 2003). PPHW: Pitch Pine-Heath Woodland, variant of PPSOW that develops on cleared land or in frost pockets (Reschke, personnal communication), similar to (but with no catbrier) pitch pine-Pennsylvania sedge woodland (CEGL006385) (NatureServe, 2003); also similar to (but with fewer shrubs) pitch pine-blueberry species-black huckleberry woodland (CEGL005046 ECS) (NatureServe, 2003). $\mathrm{HE}+\mathrm{S}$ : heath and sand, sparse early successional vegetation on cleared land. No equivalents. Non-barrens types: PPOF, pitch pine-oak forest (NYNHP, 2002b), in part pitch pine-scarlet oak-bayberry forest (CEGL006381) and possibly in part pitch pine-black oak, rock chestnut oak forest (CEGL006290) (NatureServe, 2003). COF: coastal oak forest, coastal oak-heath forest (NYNHP, 2002b), scarlet oak-black oaksassafras-hillside blueberry forest (CEGL006375 ECS) (NatureServe, 2003).

${ }^{\mathrm{b}}$ See Section 1 for Latin names. 
used to predict the amount of barrens vegetation (cover) by type 50 years in the future, based on trajectories of past vegetation change. The reasonableness of the prediction was then assessed based on our understanding of pine barrens community dynamics.

\section{Methods}

\subsection{Study area}

In 1993, the Pine Barrens Core Preservation area $(22,275 \mathrm{ha})$ was created on Long Island in central Suffolk County, NY (CPBJPPC, 1995). New development is prohibited or redirected from the Core area, and it is buffered by a 22,275 ha Compatible Growth Area in which appropriate patterns of development are allowed (Fig. 1). Most of the Core is located on coarsetextured, excessively well-drained, nutrient-poor Plymouth-Carver association soils on glacial outwash and moraine (USDA-SCS, 1975). Within the Core are 17,300 ha of matrix pine-oak forest with embedded patches of woodland, shrubland, and grassland. A
5,060 ha study area was selected within the Core (Fig. 1) because it contains dwarf pine plains, and has a well documented fire history (Windisch, unpublished data). Designation of plant community types in our study area follows descriptions of the New York Natural Heritage Program (NYNHP, 2002b). Modifications have been made to more clearly indicate vegetation structure, and to correspond to descriptions of similar vegetation in other northeastern barrens (Table 1).

\subsection{Historic vegetation and fire}

Most of Long Island probably was covered by oak or other hardwood forests at the time of European settlement in the mid-1600s (Backman, 1984; Kurczewski and Boyle, 2000). After settlement Long Island forests were extensively cut for fuelwood, and in the 1880 s fires as large as 40,000 ha repeatedly swept through central Suffolk County (Tredwell, 1912). Some hardwood forests apparently were converted to pitch pine barrens, which covered as much as 100,000 ha at their maximum extent.

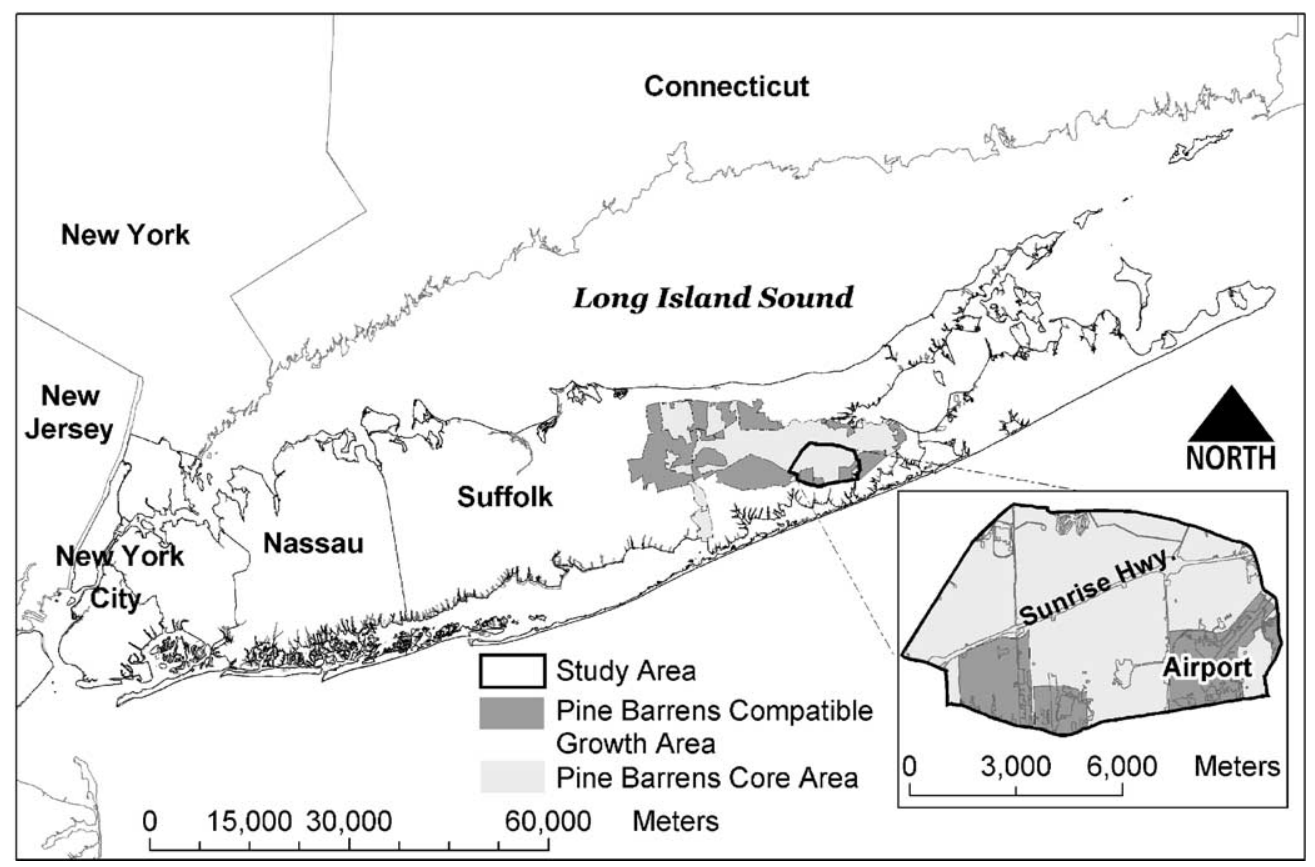

Fig. 1. Location of the 5,080 ha study area within the Core Preservation area of the Central Pine Barrens, Long Island, New York. Data sources: NY State Dept. of Environmental Conservation, NY State Dept. of Transportation, ESRI, Central Pine Barrens Commission, The Nature Conservancy. 
Fires near Native American settlements are believed to have been common prior to European colonization (Backman, 1984; Patterson and Sassaman, 1988) and could have created localized areas of barrens and grassland vegetation (Motzkin and Foster, 2002). Forests around Deep Pond, about $15 \mathrm{~km}$ northwest of the dwarf pine plains, seem to have been burned by intense fires at least eight times in the past 2200 years based on charcoal in sediment cores (Backman, 1984). Pitch pine and oak pollen are common in pre-Columbian sediments in the Deep Pond core, indicating the presence of either pine-oak woodland or barrens vegetation. The most likely area for ancestral pine barrens prior to European settlement was on the Westhampton outwash fan, in the area of the modern dwarf pine plains (Kurczewski and Boyle, 2000).

Fires burned extensively on Long Island throughout the 18th and 19th centuries (Kurczewski and Boyle, 2000). The earliest aerial photographs of the study area were taken in 1930, and despite their low quality they reveal overlapping scars from numerous severe, duff-consuming fires. We used aerial photographs taken 1938, 1940, 1947, 1961, 1969, 1970, 1980, 1985-86 to delineate perimeters of historic fires (Fig. 2). Fire dates were determined, where possible, from local fire department records.

\subsection{Cover type mapping}

Ecological community characteristics used to define vegetation cover types included height of pitch pines (i.e. dwarf or arborescent), percent tree canopy cover, percent of tree cover contributed by pines or oaks, and presence of an intact shrub layer (Table 1). Cover-type maps were delineated using stereo pairs of aerial photographs taken in 1938 and 1961 (both 1:20 000), and 1996 (1:1 200) (Fig. 3). Each map was digitized and rectified using a geographic information system (ARCVIEW). Total hectares of each cover type for each year were derived from these maps. Cover types for 1994 were estimated using the 1996 map for areas outside the perimeter of a 1,250 ha

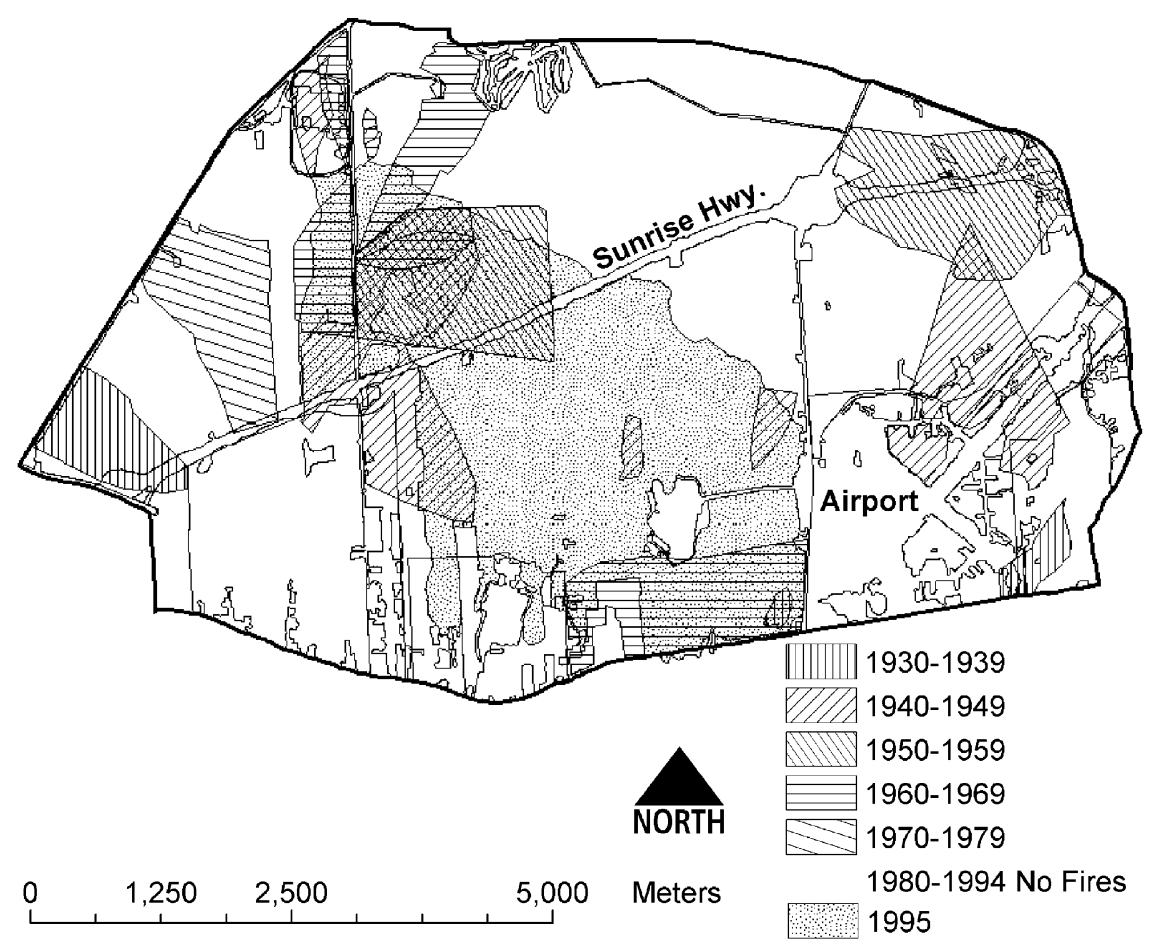

Fig. 2. Location of wildfires in the study area, 1930-1996, within the Central Pine Barrens, Long Island, New York. Data sources: NJ State Dept. of Environmental Protection, NY State Dept. of Transportation, ESRI, Long Island Central Pine Barrens Commission, The Nature Conservancy. 


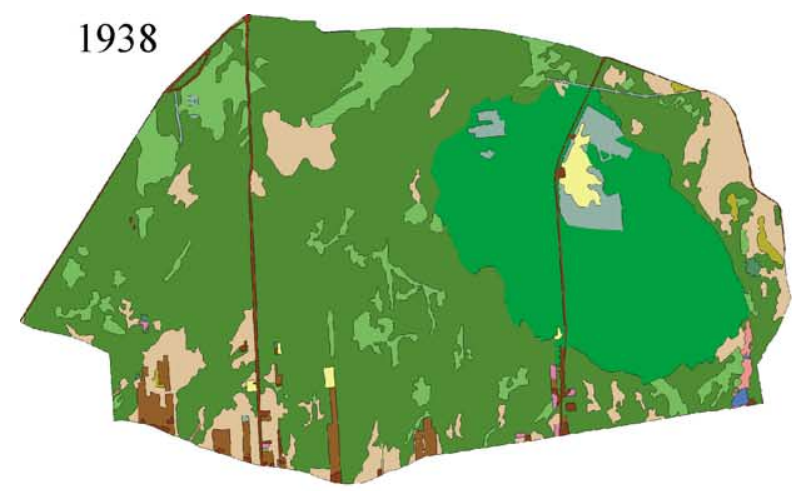

SO - Scrub oak shrubland

DPP - Dwarf pine plains PPOHW - Pitch pineoak-heath woodland PPOF - Pine-oak forest

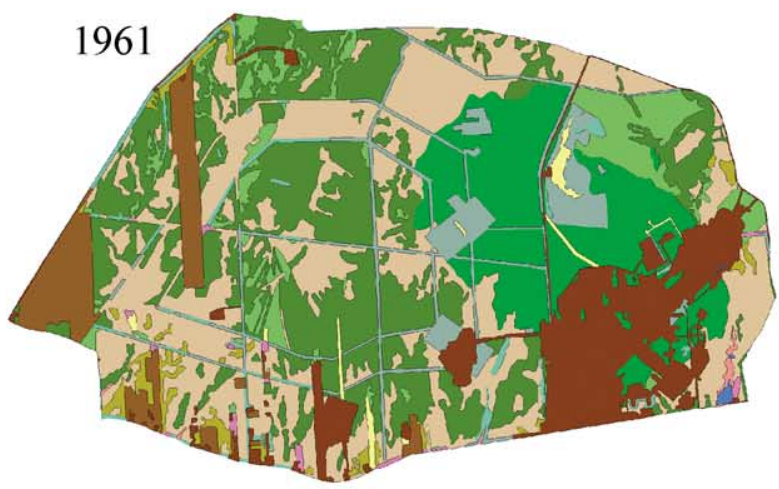
COF - Coastal oak forest S - Sand HE - Heath PPHW - Pitch pine-heath woodland G - Grass-landscape AL - Agriculture DL - Developed W - Surface water Wt - Freshwater wetland
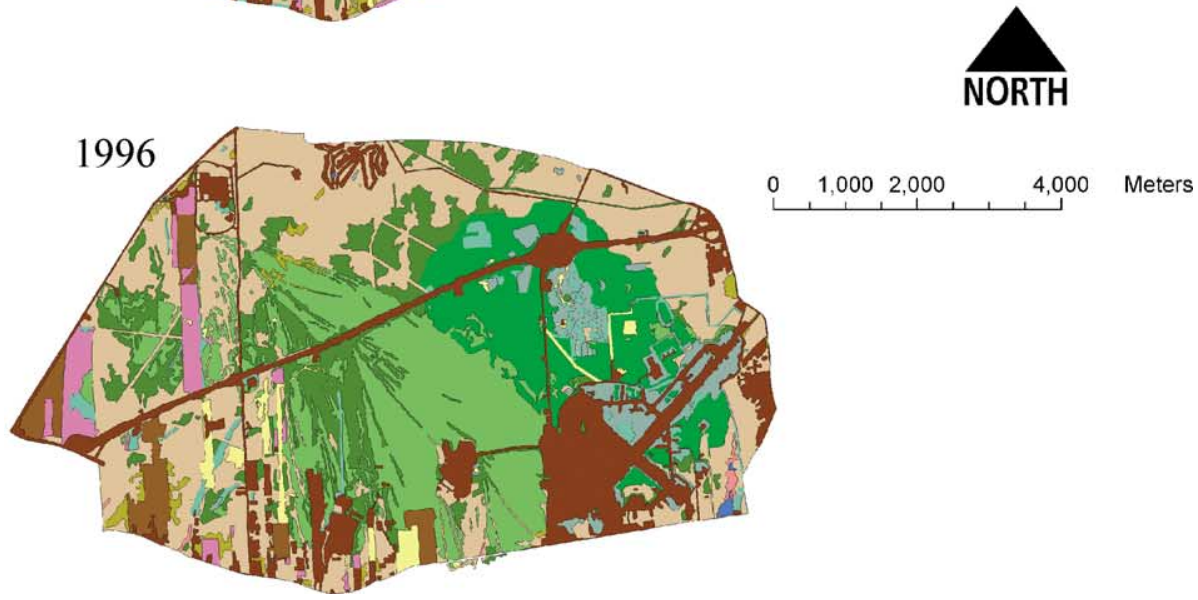

Fig. 3. Cover types for 1938, 1961 and 1996 in the study area, within the Core Preservation area of the Central Pine Barrens, Long Island, New York. Data sources: Vegetation cover from the Dept. of Forestry and Wildlife Management, University of MA, Amherst, 1997, 1:24,000. Polygons >2 ha are labeled. Map produced by The Nature Conservancy, copyright 2002.

wildfire that occurred in August 1995. Cover types within the fire perimeter were taken from a vegetation map prepared in 1990 by E. Lamont and M. Shea (Southampton, 1993).

\subsection{Conceptual models}

Three conceptual models were developed, based on knowledge of life histories and fire survival attributes 
Table 2

Requirements and fire survival attributes of dominant species in the study area ${ }^{\mathrm{a}}$

\begin{tabular}{|c|c|c|c|c|c|c|c|}
\hline Species & $\begin{array}{l}\text { Required for seedling } \\
\text { establishment }\end{array}$ & $\begin{array}{l}\text { Seedling } \\
\text { juvenile } \\
\text { period } \\
\text { (years) }\end{array}$ & $\begin{array}{l}\text { Sprout } \\
\text { juvenile } \\
\text { period } \\
\text { (years) }\end{array}$ & Fire survival mechanisms and limiting factors & $\begin{array}{l}\text { Top-kill } \\
\text { interval } \\
\text { tolerated } \\
\text { (years) }\end{array}$ & $\begin{array}{l}\text { Modal fire } \\
\text { return } \\
\text { interval } \\
\text { (years) }\end{array}$ & Refs. \\
\hline $\begin{array}{l}\text { Pinus rigida } \\
\text { Mill. (pitch pine) } \\
\text { dwarf, serotinous }^{\mathrm{b}}\end{array}$ & $\begin{array}{l}\text { Partial to full sun; } \\
\text { exposed mineral soil }\end{array}$ & $4-8$ & $3-4$ & $\begin{array}{l}\text { Basal sprouting after top-kill }<60 \text {-year-old via } \\
\text { dormant buds at mineral soil surface; shrub } \\
\text { growth form shortens juvenile period; Canopy } \\
\text { seedbank-direct reseeding after stand } \\
\text { replacing fire. }\end{array}$ & $2-60$ & $7-30$ & $\begin{array}{l}\text { Little and Somes, 1964; } \\
\text { Good and Good, 1975; } \\
\text { Ledig and Little, 1979; } \\
\text { Windisch, } 1999\end{array}$ \\
\hline $\begin{array}{l}\text { Pinus rigida } \\
\text { Mill. (pitch pine) } \\
\text { tree-form }\end{array}$ & Same as above & $8-12$ & $3-4$ & $\begin{array}{l}\text { Basal or bole sprouting in stems }<40 \text { years } \\
\text { depending on intensity; in older stem; } \\
\text { bark resistant to all surface and most crown } \\
\text { fires; canopy seedbank from serotinous } \\
\text { trees; seed re-establishment from survivors } \\
\text { or from outside burn after stand replacing } \\
\text { fire. Life span: } 200-300 \text { years. }\end{array}$ & $4-40$ & $\begin{array}{l}15-40 \\
\text { serotinous; } \\
20-60 \text { non- } \\
\text { serotinous }\end{array}$ & $\begin{array}{l}\text { Little and Somes, 1956; } \\
\text { Andresen, 1959; Little, } \\
\text { 1959; Fowells, } 1965\end{array}$ \\
\hline $\begin{array}{l}\text { Quercus ilicifolia } \\
\text { Wang. (scrub oak) }\end{array}$ & $\begin{array}{l}\text { Reduced populations } \\
\text { of acorn-consuming } \\
\text { wildlife }\end{array}$ & $>10 ?^{\mathrm{c}}$ & $3-4$ & $\begin{array}{l}\text { Root crown sprouting after top-kill via buds } \\
\text { in mineral soil; shrub growth form shortens } \\
\text { juvenile period; without fire } 35-100 \text { years } \\
\text { shade from tree oaks will eliminate species. } \\
\text { Acorn production declines with age. } \\
\text { Susceptible to repeated frost damage. }\end{array}$ & $1-100 ?$ & $5-35$ & $\begin{array}{l}\text { Little et al., 1958; } \\
\text { McNamara, 1960; } \\
\text { Wolgast, 1972; Wolgast } \\
\text { and Stout, 1977; Unnasch, } \\
\text { 1990; Motzkin et al., } 2002\end{array}$ \\
\hline $\begin{array}{l}\text { Gaylussacia baccata } \\
\text { (Wang) Koch (black } \\
\text { huckleberry) }\end{array}$ & $\begin{array}{l}\text { Rhizomatous/clonal; } \\
\text { seedlings rare }\end{array}$ & Not applicable & Not applicable & $\begin{array}{l}\text { Sprouts from rhizomes within and just below } \\
\text { the duff layer, so likely to be killed by severe } \\
\text { ground fires that consume duff. Susceptible } \\
\text { to repeated frost damage. }\end{array}$ & $?$ & $?$ & $\begin{array}{l}\text { Reiners, 1965; } \\
\text { Motzkin et al., } 1996\end{array}$ \\
\hline $\begin{array}{l}\text { Vaccinium pallidum } \\
\text { Ait. (low blueberry) }\end{array}$ & $\begin{array}{l}\text { Rhizomatous/clonal; } \\
\text { seedlings rare }\end{array}$ & Not applicable & Not applicable & $\begin{array}{l}\text { Sprouts from rhizomes in upper mineral soil; } \\
\text { taproot to }>70 \mathrm{~cm} \text {, so able to survive severe } \\
\text { ground fires. }\end{array}$ & $?$ & $?$ & Reiners, 1965 \\
\hline $\begin{array}{l}\text { Quercus velutina } \\
\text { Lam. (black oak) }\end{array}$ & $\begin{array}{l}\text { Full to partial sun; } \\
\text { mineral soil with } \\
\text { light leaf litter cover }\end{array}$ & $20-40$ & $20-40$ & $\begin{array}{l}\text { Rootcrown sprouting after top-kill } \\
<150 \text {-year-old via buds in mineral soil; } \\
\text { well-protected from low intensity surface fires } \\
\text { by thick bark and rot resistance. Advanced } \\
\text { regeneration enhanced by periodic fire. }\end{array}$ & $4-150$ & $40-+100$ & $\begin{array}{l}\text { Roth and Hepting, 1943; } \\
\text { Fowells, 1965; Abrams, } \\
1992\end{array}$ \\
\hline $\begin{array}{l}\text { Quercus alba } \mathrm{L} \text {. } \\
\text { (white oak) }\end{array}$ & $\begin{array}{l}\text { Full to partial sun; } \\
\text { light/moderate } \\
\text { litter cover }\end{array}$ & $20-50$ & $20-50$ & Same as above, except sprouting $80-100$ years. & $4-+80$ & $50-+100$ & $\begin{array}{l}\text { Roth and Hepting, 1943; } \\
\text { Fowells, 1965; Abrams, } \\
1992\end{array}$ \\
\hline $\begin{array}{l}\text { Quercus stellata } \\
\text { Wang. (post oak) }\end{array}$ & Same as above & $20-30$ & $15-25 ?$ & $\begin{array}{l}\text { Rootcrown sprouting after top-kill via buds } \\
\text { in mineral soil; some protection from surface } \\
\text { fires by medium thick bark and rot resistance. }\end{array}$ & $4-100 ?$ & $25-+50$ & $\begin{array}{l}\text { Fowells, 1965; Elias, } \\
\text { 1987; Windisch, } 1999\end{array}$ \\
\hline $\begin{array}{l}\text { Quercus coccinia } \\
\text { Muenchh. (scarlet oak) }\end{array}$ & $\begin{array}{l}\text { Full to partial sun; } \\
\text { light leaf litter cover }\end{array}$ & $20-50$ & $20-50$ & $\begin{array}{l}\text { Root crown sprouting in stems }<150 \text { years; } \\
\text { limited protection from surface fires by thin } \\
\text { bark; prone to rot. }\end{array}$ & $4-150$ & $50-+100$ & $\begin{array}{l}\text { Roth and Hepting, 1943; } \\
\text { Fowells, 1965; Abrams, } \\
1992\end{array}$ \\
\hline
\end{tabular}

\footnotetext{
${ }^{\text {a }}$ Modified from Windisch, 1999

${ }^{\mathrm{b}}$ Closed cones that open when heated, releasing seeds.

${ }^{c}$ Indicates uncertain or unknown.
} 


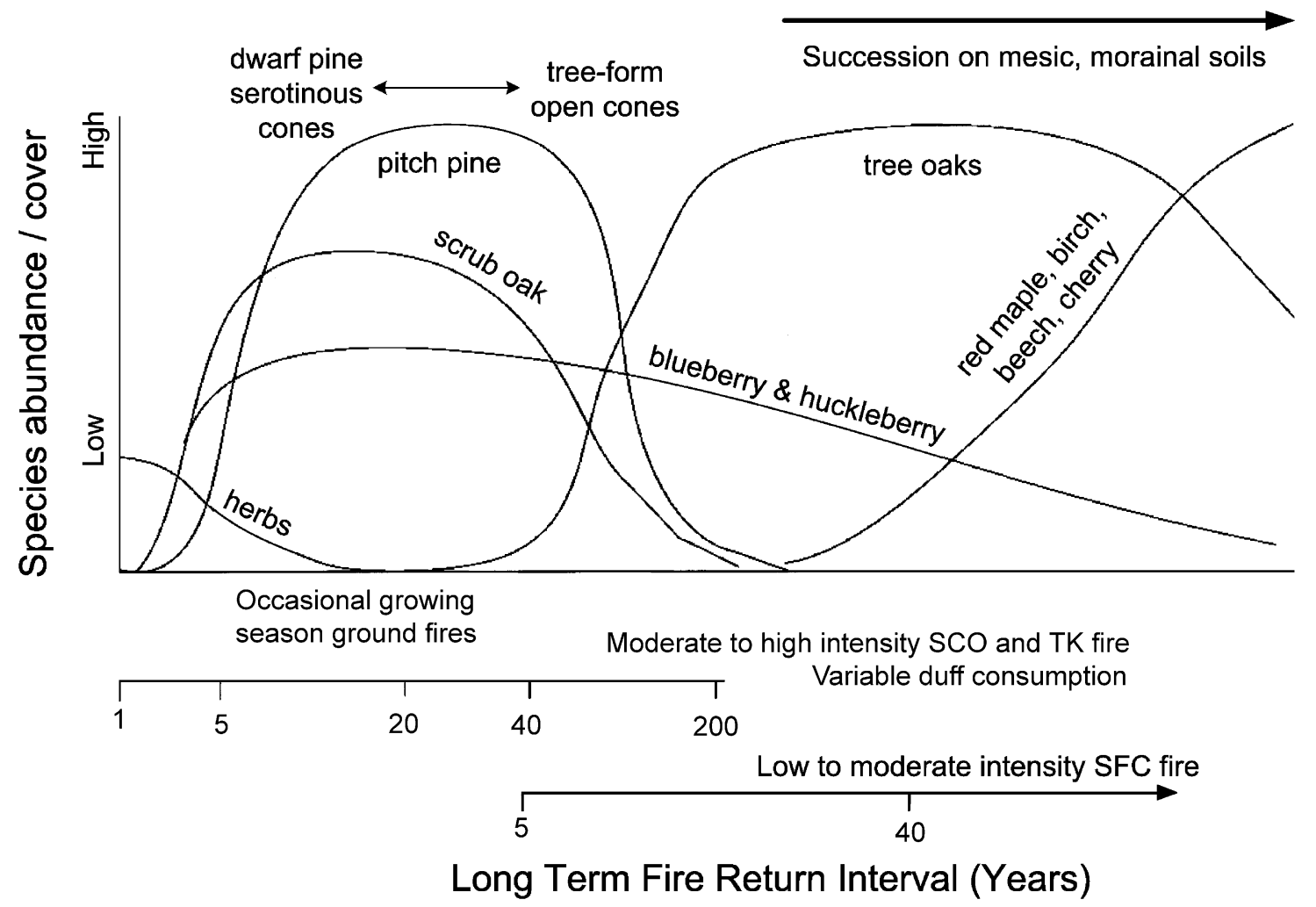

Fig. 4. Conceptual model of species responses to fire regime. TK is a top-killing, high intensity (temperatures) surface or crown fire, sometimes with an associated ground fire. SCO is a scorching, moderate intensity surface fire that may heat-kill small-medium size trees. SFC is a surface fire, typically low intensity in the dormant season, that top-kills only the smallest woody stems, and burns only surface fuels above the duff layer. Ground fire burns the forest floor duff layer.

of dominant pine-barrens species (Table 2), fire history (Fig. 2), historic vegetation change with time (Fig. 3), post-wildfire vegetation recovery (Jordan and Gurevitch, unpublished data), and published literature. The first model depicts the relative abundance of dominant barrens plant species or species groups under different fire regimes (Fig. 4). The second is a box-and-arrow flowchart (state-transition model) depicting the fire regimes that maintain pine barrens ecological community types (states), or that result in transitions from one type to another (Fig. 5). The third is a box-and-arrow flowchart that depicts successional pathways following land clearing, and suggests future conditions to be expected under different fire regimes and clearing scenarios (Fig. 6).

\subsection{Quantitative model}

A quantitative computer simulation model was used to predict the amount of barrens vegetation (cover) by type 50 years in the future, based on trajectories of past vegetation change. Transition matrices of cover type change were derived from the cover type maps (Fig. 3) for the time intervals 1938-1961, 1961-1996, and 1938-1996. The matrices show the number of hectares that changed from one cover type to another, or remained the same, for each time interval (Table 3).

The transition matrices were used to derive annual transition parameters as input for STELLA II (Peterson and Richmond, 1994), which was adapted to predict cover type change among several time periods in northeastern pine barrens (Finton, 1998). The structure of the model followed a Markovian replacement process (Horn, 1981) in which a transition to any state depends only on the state from which it came, and not on any prior states (Horn, 1975). Transition probabilities based on changes occurring during multiyear time periods were converted to annual transition 


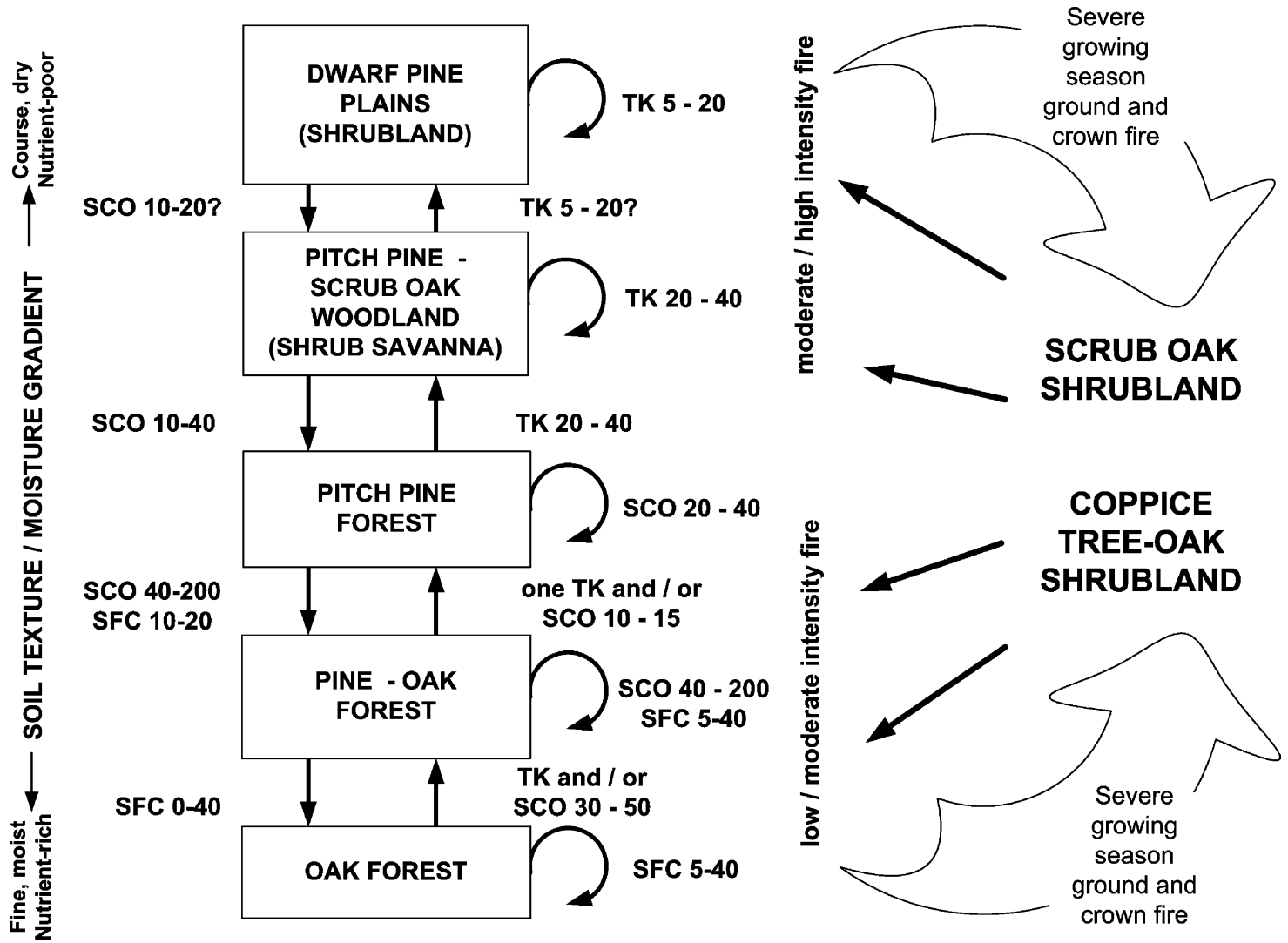

Fig. 5. Conceptual model for pine barrens ecological community types. This state-transition model depicts fire regimes that maintain vegetation types (states; curved arrows), or that result in transitions from one type to another (straight arrows between boxes). The large curved arrows indicates fire type that could convert any of the vegetation types represented by boxes into shrubland. All time intervals are approximate. A severe fire consumes all organic matter on the soil surface. For abbreviations see Fig. 4.

Table 3

Transition matrix of cover type change (ha) in the study area, 1938-1996

\begin{tabular}{|c|c|c|c|c|c|c|c|c|c|}
\hline Cover type $^{a}$ & SO & DPP & PPSOW & PPHW & $\mathrm{HE}+\mathrm{S}$ & PPOF & $\mathrm{COF}$ & $\mathrm{DL}+\mathrm{AG}+\mathrm{G}$ & Total 1938 \\
\hline $\mathrm{SO}$ & 77 & 0 & 62 & 6 & 5 & 177 & 2 & 83 & 413 \\
\hline DPP & 115 & 496 & 15 & 27 & 129 & 23 & 0 & 214 & 1019 \\
\hline PPSOW & 653 & 3 & 492 & 56 & 74 & 1052 & 18 & 508 & 2856 \\
\hline PPHW & 0 & 0 & 0 & 1 & 1 & 2 & 0 & 2 & 6 \\
\hline $\mathrm{HE}+\mathrm{S}$ & 0 & 25 & 4 & 38 & 39 & 9 & 0 & 25 & 139 \\
\hline PPOF & 37 & 1 & 20 & 6 & 15 & 232 & 35 & 115 & 460 \\
\hline $\mathrm{COF}$ & 0 & 0 & 0 & 1 & 0 & 10 & 0 & 5 & 17 \\
\hline $\mathrm{DL}+\mathrm{AG}+\mathrm{G}$ & 5 & 1 & 1 & 2 & 11 & 19 & 2 & 123 & 165 \\
\hline Total 1996 & 888 & 526 & 595 & 136 & 275 & 1523 & 58 & 1076 & 5075 \\
\hline
\end{tabular}

Each number represents the area of the row cover type present in 1938 that had converted to the column cover type in 1996. Add across rows for cover type totals in 1938. Add down columns for cover type totals in 1996. For example, in 1996 there were 888 ha of SO; in 1938,77 of the 888 ha were SO, 115 ha were DPP and 653 ha were PPSOW.

${ }^{\text {a }}$ Cover type abbreviations are as for Table $1 ; \mathrm{DL}+\mathrm{AG}+\mathrm{G}$ is developed, agricultural, and grass/landscaped. 


\section{SUCCESSION}

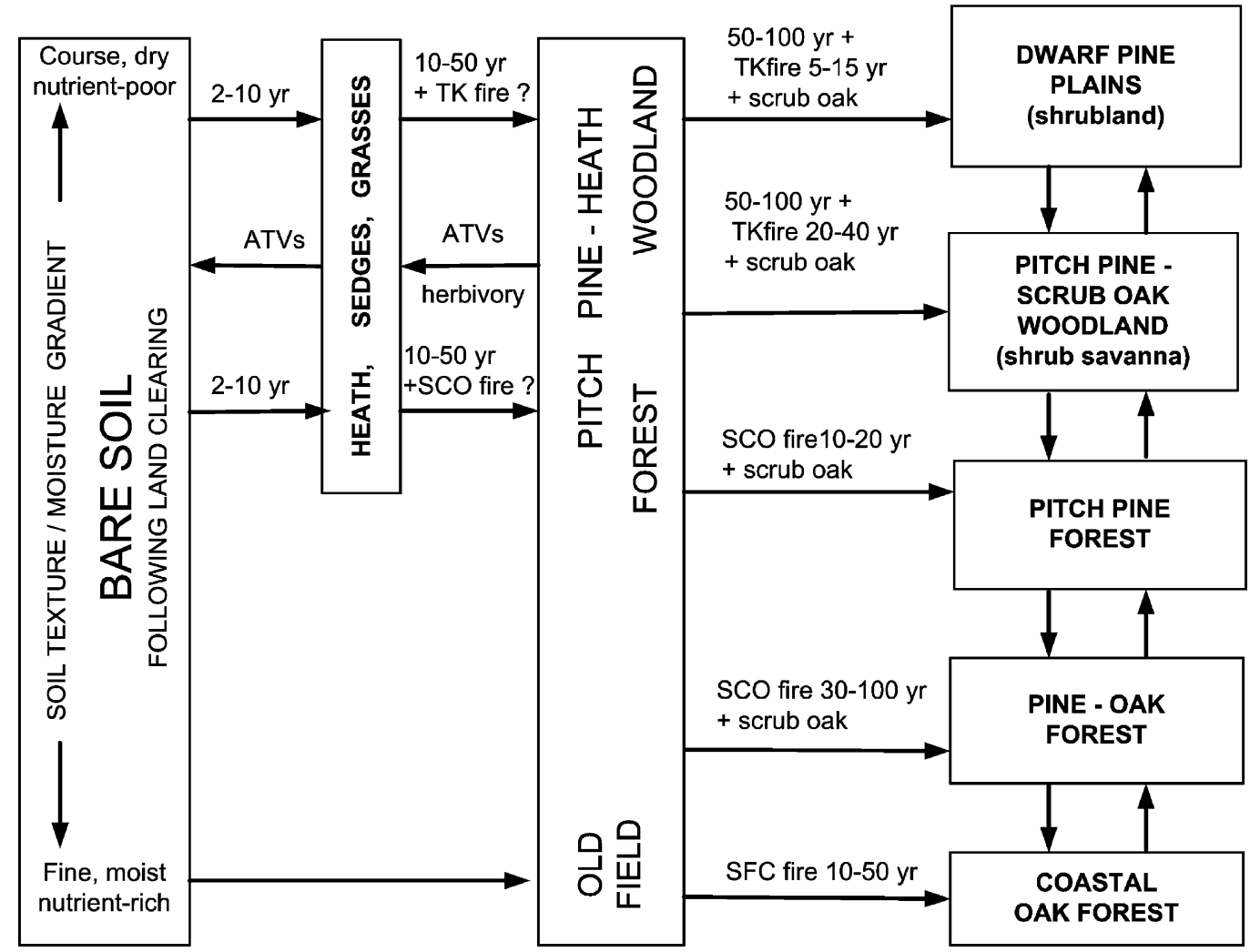

Fig. 6. Conceptual model of community change following land clearing in the Central Pine Barrens, Long Island, New York. This statetransition model depicts successional pathways following land clearing that removes roots and exposes bare soil. All time intervals are approximate. Arrows going to the right indicate successional transitions, and fire regimes that facilitate transitions. ATV is all-terrain vehicles. For abbreviations see Fig. 4.

probabilities, which remained constant throughout the simulation.

Predictions of the amount of each cover type in 2046 were based on overall rates of vegetation change for 1938-1996, as there was little difference between predictions based on transitions between 1938-1961 and 1961-1996. Predictions assume that factors influencing vegetation development in 1938-1996 would continue into the future. Analysis using STELLA II simulation models provides no information on causes for, or spatial relationships among, transitions. The reasonableness of the simulation model predictions were assessed based on our understanding of pine barrens community dynamics captured in the conceptual models.

\section{Results}

Most wildfires in the Core Preservation study area occurred in the spring prior to leaf out (Fig. 7). From 1938 to the present the size of fires has decreased $(P=0.001)$ (Fig. 8), and the average area burned per year has generally declined (Fig. 9), with the 1995 Sunrise Wildfire being a notable exception. Between 1938 and 1994, $70 \%$ of the 5,060 ha study area had not burned for at least 60 years; the 1995 fire reduced the unburned area to $\sim 55 \%$ (Fig. 2).

Barrens community types (dwarf pine plains, pitch pine-scrub oak woodland, heath, pitch pine-heath and scrub oak shrubland) declined from $90 \%$ of total vegetation cover ( $87 \%$ of the study area) in 1938 to 


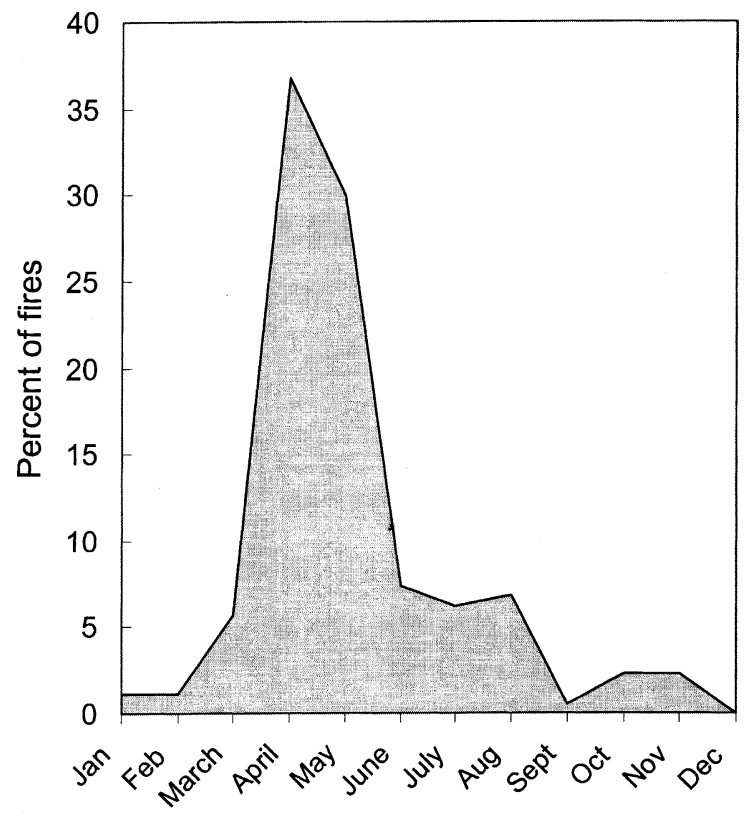

Fig. 7. Seasonality of fire. Data are for 177 fires for which dates are available, that occurred between 1938 and 1995 in the Central Pine Barrens, Long Island, New York.

an estimated $44 \%$ of vegetation (36\% of the study area) in 1994 (Fig. 10). Barrens loss was due to conversion to pitch pine-oak forest, or to development

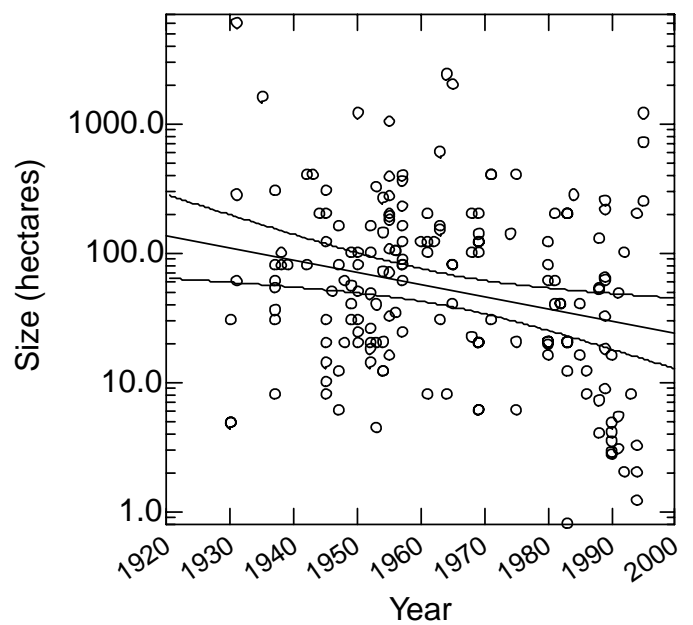

Fig. 8. Change in size of fires, 1930-1995. Data are for 177 fires for which size is available, in the Central Pine Barrens, Long Island, New York. Confidence interval on the regression line is $95 \%, P=0.001$.

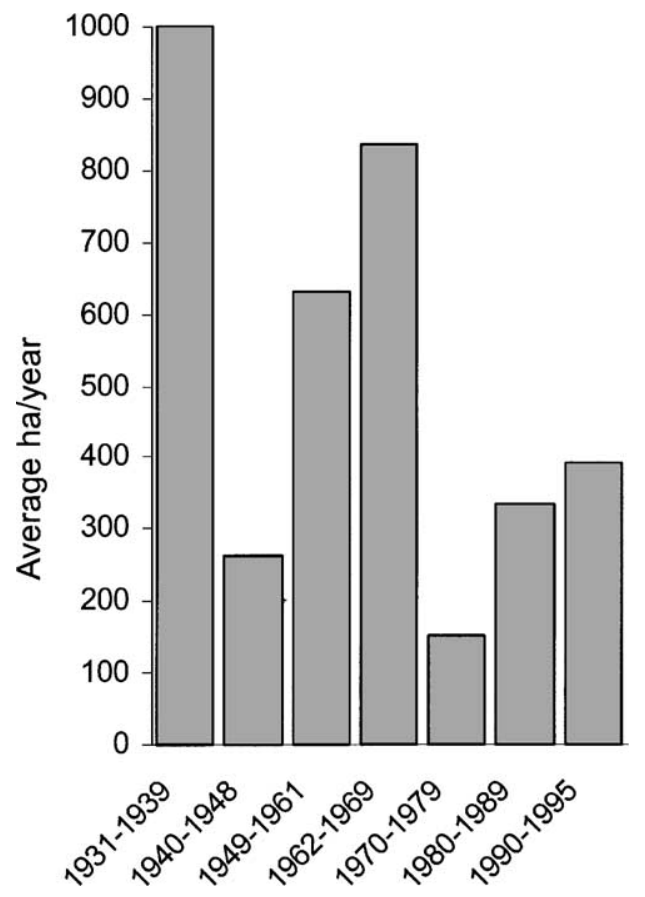

Fig. 9. Average number of hectares burned per year. Data are for 177 fires for which size is available, that occurred between $\sim 1930$ and 1995 in the Central Pine Barrens, Long Island, New York. Time intervals vary slightly due to uncertainties in some dates.

(Table 3). Declines were greatest for scrub oak shrubland and pitch pine-scrub oak woodland, which declined by $84 \%$ (347 ha) and 72\% (2065), respectively (Fig. 10). The 1,215 ha Sunrise Wildfire of 1995 reversed this trend by creating 820 ha of scrub oak shrubland from former dwarf pine plains ( $38 \mathrm{ha})$, pitch pine-scrub oak woodland ( $~ 97$ ha), pitch pineheath woodland ( $\sim 16 \mathrm{ha})$ and pitch pine-oak forest ( $~ 583$ ha), increasing barrens cover to $60 \%$ of vegetation cover in 1996 (Fig. 10). Pitch pine sprouts and seedlings within burned woodland and forest exceeded $2 \mathrm{~m}$ in height by 2002, and as they continue to grow and overtop the shrubs, scrub oak shrubland will again decline.

Between 1938 and 1961, the sum of the developed, agricultural, and grass/landscaped cover types increased by 726 ha $(440 \%)$, heath/sand increased by 214 ha $(154 \%)$, and pitch pine-heath woodland increased by 79 ha (1212\%; Fig. 10). These increases resulted from land clearing for agriculture, an airport, residential housing, and sand roads, as well as vegetation succession on cleared soils (Fig. 3). Most of the 


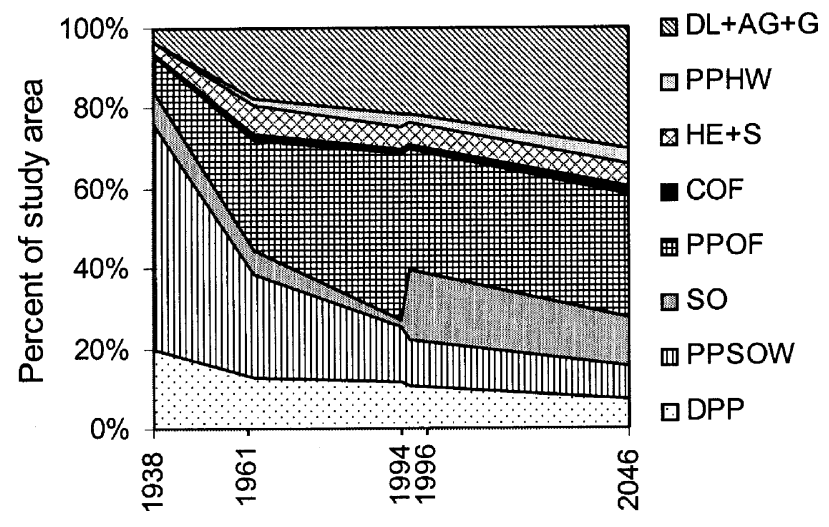

Fig. 10. Change in area of cover types, 1938-1996 and predicted for 2046. Area is expressed as a percent of the 5,080 ha study area, within the Central Pine Barrens, Long Island, New York. For cover types see Fig. 3.

land cleared or converted had been dwarf pine plains and pitch pine-scrub oak woodland in 1938. Between 1961 and 1996, an additional 184 ha (21\%) were converted to developed, agricultural and grass/landscaped, primarily as a result of construction of a major highway and a golf course (Fig. 3). Heath and exposed sand decreased by 70 ha (21\%) between 1961 and 1996 , as a result of succession to pitch pine-heath woodland.

Based on cover type transitions for 1938 to 1996, the Stella II simulation model predicted that by 2046 , there would be increases in the developed, agricultural, and grass/landscaped cover type (44\%),

Table 4

Vegetation cover (ha) 1938-1996, and predicted to 2046

\begin{tabular}{lrrrrr}
\hline Cover type $^{\text {a }}$ & 1938 & 1961 & 1994 & 1996 & $\begin{array}{l}2046 \\
\text { STELLA } \\
\text { prediction }\end{array}$ \\
\hline SO & & & & & \\
DPP & 415 & 317 & 68 & 888 & 614 \\
PPSOW & 2862 & 1301 & 692 & 595 & 395 \\
PPHW & 6 & 85 & 152 & 136 & 196 \\
HE + S & 139 & 353 & 284 & 279 & 281 \\
PPOF & 460 & 1393 & 2110 & 1527 & 1580 \\
COF & 17 & 97 & 57 & 57 & 99 \\
DL + AG + G & 165 & 891 & 1082 & 1076 & 1545 \\
Total natural & 4918 & 4194 & 3955 & 4007 & 3540 \\
$\quad$ vegetation & & & & & \\
Total all & 5084 & 5085 & 5037 & 5082 & 5085 \\
$\quad$ cover types & & & & & \\
\hline
\end{tabular}

${ }^{\text {a }}$ Cover type abbreviations are as for Table 1 ; $\mathrm{DL}+\mathrm{AG}+\mathrm{G}$ is developed, agricultural, and grass/landscaped. coastal oak forest (75\%) and pitch pine-heath woodland $(44 \%)$, and decreases in scrub oak shrubland $(-31 \%)$, pitch pine-scrub oak woodland $(-34 \%)$, and dwarf pine plains $(-28 \%)$, and little change in pitch pine-oak forest or heath/sand (Table 4; Fig. 10).

\section{Discussion}

\subsection{Fire sorting of pine barrens species}

Effects of fire on plants depend on fire line intensity (temperature flame lengths), fire severity (duff consumption), amount of fuel, fire duration, fire return intervals, weather during and after the fire, and season of burning. Most wildfires in the Long Island pine barrens have occurred in the spring prior to leaf out (Fig. 7) when winds are often high, humidity low, and surface litter and fine fuels are dry and readily combustible. Although spring fires may be of high intensity, deep duff is usually moist and unlikely to burn. Plants may be top-killed, but root systems of pine barrens species survive. Severe, duff-consuming fires are most likely to occur following prolonged drought, typically during the summer. Severe fires occur less often than high intensity springtime fires, for once the duff is consumed it takes many years for enough duff to accumulate to support another severe fire.

Root damage and total plant kill are more likely for severe, growing season than for dormant season fires, especially for species with basal buds in or just below the duff layer, such as pitch pine and huckleberry. 
Scrub oak can survive even the most severe fires. However, scrub oak was eliminated from experimental plots in Massachusetts by a severe growing season burn under drought conditions, followed by summer burns repeated for several years. Deep duff $(6-8 \mathrm{~cm})$ with extended burn time contributed to the high mortality. Scrub oak has also been eliminated from experimental plots on LI, by repeatedly cutting back the scrub oak throughout the summer for three years (Gurevitch et al., unpublished data).

If sufficient grasses, sedges and other rapidly drying vegetation are present, they can provide enough fine fuels to support a fire every 2-4 years. Few woody species can survive top-killing that frequently, especially if fires occur during the growing season (Dunwiddie et al., 1997). Pitch pines rarely form cones on growth $<5$ years of age, and would eventually be eliminated, as sprouting ability declines with age. Under such conditions, graminoids, other herbaceous plants, and possibly low blueberry could persist and spread (Fig. 4). When fire return intervals are short ( $<5$ years), heavier fuels and duff do not accumulate, so fires would be low in intensity and severity.

With fire return intervals of 5-10 years fuel loads would be higher, but not enough duff would accumulate to support deep-burning, severe fires (Fig. 4). Moderate intensity, patchy fires would be typical, leaving unburned refugia in which graminoids and fire-sensitive plant and insect species could persist (Gibson et al., 1999). Scrub oak and pitch pine could establish and persist, but would be frequently topkilled. Repeated top-killing fires at 5-20 year intervals select for multi-stemmed, dwarf pitch pines with precocious serotinous cone production (Good and Good, 1975) (Table 2; Fig. 4). Mineral soil exposed by fire would enable episodic pine regeneration from seed (Andresen, 1959).

If top-killing fires do not occur for at least 15 or 20 years, young pines are able to grow tall $(>4 \mathrm{~m})$ with a single stem (Fig. 4). Subsequent moderate intensity scorching fires might heat-kill needles and twigs, but epicormic sprouting from branches and boles would refoliate crowns. Young pines might be top-killed, but would resprout from root collars. Mortality of mature pines is most likely to occur following very intense fires during the growing season, as occurred in 1995. Only following occasional severe ground fires, or repeated high intensity spring fires, would mineral soil be exposed and allow pine seedling establishment (Andresen, 1959; Fig. 4).

With increasingly longer intervals between top-killing fires ( $>30-40$ years), tree oaks are able to establish, persist, and reproduce from seed. Most tree oaks, especially those $<50-60$-year-old, can survive topkilling by occasional severe growing season fires, because basal buds are deep in mineral soil. As tree oaks invade, the canopy closes, and duff accumulates, pitch pines and scrub oak decrease due to lack of a mineral seed bed and/or increasing shading (Table 2; Fig. 4). Huckleberry and blueberry can persist in closed canopy forests, but grow and fruit less vigorously than under open canopy barrens communities. Frequent, low intensity surface fires favor tree oaks by top-killing faster growing, fire-sensitive competitors like red maple (Acer rubrum L.), birch (Betula spp.), beech (Fagus grandifolia Ehrh.) and black cherry (Prunus serotina Ehrh.) (Fig. 4; Abrams, 1992). These competing mesic hardwoods are now rare within the Central Pine Barrens, but they could increase on mesic sites in response to fire suppression.

\subsection{Effects of fire on ecological communities}

Fire regimes shape ecological communities by differentially favoring plant species according to their fire survival attributes (Noble and Slatyer, 1977; Rowe, 1983). Repeated fires at intervals of $<5$ years for an extended period of time might create a grassland or heathland as a gradual result of a positive feedback loop, in which quick-drying, flammable, fire-tolerant vegetation support frequent fire (Fig. 4). Scrub oak and huckleberry are reduced in size and vigor by fires that frequent, especially when fires occur during the growing season, although the deeper-rooted blueberries would persist (Table 2; Fig. 4).

It is difficult to speculate on fire regimes that would form grassland or heathland, as most modern examples in Southern New England occur on formerly cultivated fields or pastures (Stevens, 1996; Motzkin and Foster, 2002). A possible exception is the Hempstead Plains, a formerly 16,200 ha tall grass prairie in Nassau County, Long Island (Hicks, 1892; Harper, 1912). The Plains are described by 17th century sources and apparently predate European settlement (Allen, 1997; Motzkin and Foster, 2002). Frequent fires set by Native Americans may have created the 
Plains, although evidence is lacking. To the east the Hempstead Plains transitioned into 20,000 ha of pitch pine-scrub oak barrens with tall, widely spaced pitch pines, which formed a continuum with the Central Pine Barrens (Cryan, 1981; Cryan and Turner, 1981). Fires in the Plains probably burned into the pitch pinescrub oak barrens occasionally, with some fire-free intervals $>15$ years, or pitch pines would not have been able to attain tree size.

High intensity and often severe fires recurring at intervals of 5-20 years presumably created the dwarf pine plains (Fig. 5), although the earliest historic record of the Long Island pine plains is relatively recent (Dwight, 1821). The shortest fire return intervals are thought to create the most dwarfed form of pitch pine, and maintain scattered openings in the shrub layer in which herbaceous species and low shrubs such as bearberry and golden heather can persist (Windisch, 1999). Frequent fire would also release seeds from serotinous pine cones and expose mineral soil. The pine plains may have historically burned more frequently than other areas in the Central Pine Barrens, because they are located within a broad, sandy upland - a fireshed - with no wetlands to serve as firebreaks, and which, therefore, could be affected by fires with points of origin in any direction from the Plains (Givnish, 1981; Windisch, 1999).

Aside from the dwarf pine plains, fire is less frequent and wooded communities are dominated by arborescent pines. High intensity or severe growing season burns at 20-40 year intervals would kill most pines older than 30-40 years and create an open pine canopy woodland with a dense shrub layer of scrub oak and heath shrubs-i.e. a shrub savanna, or pitch pine-scrub oak woodland (Fig. 5). Shrub cover would shade out herbaceous plants. Open canopy woodlands can also result from pine mortality caused by occasional outbreaks of the eastern pine looper (Lambdina pellucidaria). Large areas may be defoliated, reducing pitch pine densities and increasing fuel loads. Large, high intensity fires have followed looper defoliations elsewhere in the region (Fowells, 1965).

The extent to which pitch pines might seed in and increase pine cover depends on the proximity of seed sources, the amount of exposed mineral soil, and whether rainfall during the first few years following the fire favors seedling survival. In the absence of topkilling fires, but with low intensity fires frequent enough to keep duff accumulation low, pine seedlings can establish in sufficient densities to form pitch pine forest, with pine cover $>60 \%$ (Fig. 5). We did not try to map pine forest as a separate cover type, but it occurs in a patchy mosaic within pine-oak forests, probably reflecting variations in intensity and severity of historic fires. Wherever pitch pines remain dominant, the potential for stand-replacing crown fires persists.

If intense, growing season surface fires capable of scorching crown foliage return at intervals greater than 30-50 years, tree oaks can establish from seed and/or sprout following top-killing, produce acorns, and increase in abundance, especially on better soils (Figs. 4 and 5). Established oak saplings sprout vigorously after top-killing. After fire-free periods of 10-20 years, oak tree canopies close and sunlight at the forest floor declines. Large, old pitch pines may persist for 200 years or more, but cannot reproduce due to accumulating litter and duff, and lack of sunlight. Scrub oaks also decline with increasing shade. Gradually pitch pines and scrub oak disappear as pine-oak forests succeed to coastal oak forests (Fig. 5). As forests become hardwood dominated they become less flammable as the potential for crown fires declines. Deciduous canopies protect surface fuels from wind and the drying effect of the sun. In oak stands growing season fires are less likely to occur than in pine stands, and dormant season burns less likely than growing season burns to top-kill canopy oaks, which eventually dominate most stands and favor the maintenance of oak-dominated forests.

Community transitions due to succession in the absence of fire occur gradually, but a single top-killing or crown scorching fire can quickly convert a forest or woodland into a shrubland (Fig. 5). The Sunrise Wildfire of 24-25 August 1995 facilitated just such a transition. Approximately $70 \%$ of the area within the wildfire perimeter had not burned since 1930 (Fig. 2), and most of the pines were $>40$-year-old. In areas of intense crown fire coupled with severe ground fire, mortality of top-killed pines was as high as $98 \%$ (Jordan, unpublished data). The fire nearly eliminated shallow-rooted species such as huckleberry, bearberry and wintergreen, whereas deeperrooted scrub oak and blueberry have recovered quickly, as predicted by Reiners (1965). A scrub oak and blueberry shrubland resulted, with an increased abundance of golden heather, sedges and 
grasses, which may have established from soil seed banks.

Following the Sunrise Wildfire, areas near surviving pines received sufficient seed to regenerate numerous pine seedlings, and ample rain in 1996 enabled high initial survival (Gurevitch, unpublished data). In previously forested areas, many pine seedlings were more than $2 \mathrm{~m}$ tall in 2002 and will soon develop into pine woodlands and forests. In large, severely burned areas in the dwarf pine plains most pine cones and seeds were consumed by flames and few pine seedlings have established (Gurevitch, unpublished data). The resulting scrub oak shrublands may persist for decades. Regenerating pine seedlings are $<1 \mathrm{~m}$ tall, probably due to poor soil and lack of moisture (Fang and Gurevitch, unpublished data).

Scrub oak and regenerating coppice tree oaks cannot be distinguished in aerial photographs. Within our study area, tree oaks are rare today, so we infer that areas of shrubland seen on aerial photographs from 1930 s to 1980 s were predominantly scrub oak, not coppice tree oaks. In locations outside of the study area, where tree oaks are more abundant, a transition from shrubland to forest documented by aerial photographs probably represents regrowth of tree oaks from coppice. Conversion of coppice tree oak shrubland to pine-oak forest occurs more rapidly than does a transition resulting from gradual colonization of tree oaks through animal dispersal.

\subsection{Species responses to clearing}

Recently, cleared land revegetates within a few years to golden heather, bearberry, sedges, and grasses (Fig. 6). Invasive or old field species tend to appear primarily on richer soils, especially on disturbed roadsides and rights-of-way (Fig. 6). Pitch pine seedlings establish readily in pine woodland and forest areas but are slow to appear in clearings in the pine plains, where most cones are serotinous and remain closed without fire. Pines that do establish in clearings in the dwarf pine plains tend to be single-stemmed, taller and straighter than the surrounding dwarf pines, perhaps because they have never been top-killed (Good and Good, 1975). Only 50\% of pitch pines on clearings in the dwarf pine plains are serotinous compared with $\sim 90 \%$ in undisturbed plains (Jordan, unpublished data). In the absence of fire, the primary seed source is the few non-serotinous pines in the surrounding plains. Perhaps non-serotinous trees may produce some serotinous offspring, and perhaps growth form is related to serotiny, but little is known about the genetics of these traits (Givnish, 1981).

Clearings that remove rootstocks of scrub oak, huckleberry and blueberry eliminate these shrubs for decades, as they rarely reproduce from seed. It appears to take $>100$ years for the shrub understory of these successional pine-heath communities to approach the diversity and density of undisturbed sites (Motzkin et al., 1996). In general, succession proceeds more rapidly on richer soils in woodland or forest areas. Species composition varies with seed sources.

\subsection{Spatial patterns}

The effects of fire on the landscape are variable and complex in time and space, and are influenced by unpredictable ignition events, droughts, weather (wind direction and speed; humidity), long-term weather patterns, natural and human-created firebreaks, outbreaks of defoliating insects, and past land use and fire history, all of which affect the amount and distribution of natural fuels and fire behavior within them. Within a given fire, severity and intensity are typically quite variable as a result of fire-created wind patterns such as horizontal roll vortices (Haines, 1982), and "fire shadows" downwind of partial firebreaks. An unusual phenomena-crown stripes-occur as linear islands of surviving vegetation in areas blackened by crown fires (Haines, 1982). Trees and other plants in crown stripes and fire shadows often escape top-killing, and provide a seed source for nearby burned over land. These lightly burned features also serve as refugia for insects and animals. Crown stripes resulting from the 1995 Sunrise Wildfire are visible in the 1996 cover type map as linear strips of pitch pine-scrub oak woodland surrounded by scrub oak shrubland (Fig. 3).

Frost pockets may occur in low-lying areas due to cold air drainage, especially in more northerly barrens (Motzkin et al., 2002). On Long Island, frost pockets occur only in a few relict glacial meltwater channels that cross the dwarf pine plains. Scrub oaks in these channels are stunted by late spring frosts. Along the bottom of the channels scrub oaks are sparse, and the ground layer is dominated by sedges, grasses, bearberry and blueberry. 


\subsection{Vegetation change with time}

Some decreases in the area of barrens community types from 1938 to 1996 were due to residential and industrial development, especially in the dwarf pine plains and pitch pine-scrub oak woodland, where 214 and 508 ha, respectively, were lost (Table 3). However, most of the 58 year decline in barrens communities was due to the succession of 1,052 ha of pitch pinescrub oak woodland to pine-oak forest, which increased more than three-folds (Table 3; Fig. 10). Despite the reversal of these trends as a result of the 1995 fire, barrens communities will likely continue to decline if the overall pattern of reduced fire occurrence characterizing the last +60 years persists. The loss of barrens communities is probably occurring more rapidly in portions of the Pine Barrens Core Preserve that are outside of the study area, where soils are less droughty, fire return intervals longer, and tree oaks more abundant.

The STELLA prediction that scrub oak shrubland and pitch pine-scrub oak woodland would decrease by only 31 and 34\%, respectively, between 1996 and 2046 will likely underestimate actual loss rates. The prediction was based on transitions calculated for 1938-1996, a period during which 810 ha of scrub oak shrubland were created by the 1995 fire. The prediction for 2046 implicitly assumes that past fire regimes will continue into the future, including fires as severe as the 1995 fire. Examination of individual polygons of shrubland and woodland cover types which remained unburned for decades suggests a half-life of 15-30 years for scrub oak shrubland, and 20-40 years for pitch pine-scrub oak woodland. In the 23 years, between 1938 and 1961, 75\% of scrub oak shrubland and $37 \%$ of woodland were lost to succession or regrowth.

The conceptual models presented here will be updated as new data become available, and as hypotheses are tested with data from monitoring and research both of future prescribed burns and wildfires, and as vegetation succeeds in the absence of fire. Environmental conditions and land-use history vary so greatly among northeastern barrens that no one model can apply adequately to all (Finton, 1998). However, because northeastern pitch pine barrens share a common suite of species, at least some aspects of the Long Island models should be applicable to other pine barrens ecosystems. With this in mind, the Long Island models are being considered as a basis for developing conceptual models for other pitch pine barrens in the Northeast.

\section{Conclusions}

Maintaining pitch pine barrens with their full suite of plant and animal species requires frequent (i.e. at least at intervals of a few decades) disturbance to maintain open-canopy, shrub dominated communities, to expose the mineral soil needed for pitch pine seedling establishment, and to prevent invasion of tree oaks and succession to hardwood forest. Historically, wildfire, cutting, land clearing/cultivation, insect herbivory and frost damage created and maintained extensive areas of barrens. Development, fragmentation, and fire suppression during the last 50 years have resulted in loss and degradation of pitch pine barrens throughout the Northeast (Finton, 1998). Restoration and management of remnant pine barrens are urgently needed, based on: (1) a sound understanding of the life histories of barrens species; (2) the role of fire in shaping ecological communities; and (3) on past vegetation change. The conceptual ecological models presented here could provide a basis for the development of future management protocols.

Wherever possible, careful use of prescribed fire, perhaps in combination with mechanical pretreatments, is recommended. Such management is needed both to reduce fuel loads in an effort to protect human life and property, and to perpetuate fire-dependent pine barrens ecological communities. An ideal fire regime would include varied fire behaviors across the landscape and over many decades, including both low and high intensity, and low and high severity burns, in both dormant and growing seasons. Such "pyrodiversity" would maintain biodiversity (Myers, personnal communication).

We face many challenges in implementing an ideal fire regime. Reproducing (creating) with prescribed fire the effects of high intensity, top-killing wildfires which are needed to maintain open canopy barrens communities may be possible only where barrens are large and extensive, and development limited, as in the 281,000 ha New Jersey Pinelands protected areas. 
Such prescribed fires are more complicated in smaller barrens near the wildland-urban interface, due to the risk of escape. It may also be difficult (due to air quality concerns) to implement the occasional severe, duff consuming prescribed fires which are needed to expose mineral soil seedbeds. Prescribed winter crown fires, followed by growing season low intensity backfires, may be an acceptable option. In any case, prescribed fires should always be conducted under weather conditions that send smoke aloft, or in the direction of uninhabited areas.

Where the application of prescribed fire is not practical, we need to develop and evaluate mechanical treatments which will replicate, to the extent possible, the effects of wild or prescribed fire. Mechanical clearing and low intensity prescribed burning near the wildland-urban interface would make high intensity burning in the interior more feasible. Perhaps such burns could be safely attempted in the larger portions of the Long Island Central Pine Barrens. Despite these many challenges, an active fire management program utilizing prescribed fire with appropriate mechanical treatments is probably preferable to the results of continued unmitigated wildfires.

Although unforeseen ignitions (i.e. wildfires) may bring desired ecological changes in barrens vegetation, they will become increasingly hazardous as areas on the perimeter of the preserve are developed. Adoption of ecologically sensitive-while at the same time effective-wildfire suppression techniques is needed. Current suppression tactics include bulldozing wide firebreaks to mineral soil. These clearings provide avenues for off-road vehicles and revegetate slowly. Pine barrens managers need to work cooperatively with local fire departments to evaluate the use of backfires from existing fire breaks, as an alternative to building new mineral breaks. Protection of human resources will ultimately drive barrens fuels management and wildfire suppression. It is incumbent on resource managers to help develop management practices that both preserve pine barrens and protect the public from wildfire.

\section{Acknowledgements}

We thank Janice Stone for vegetation mapping, David Goodwin for creating transition matrices, Adam Mouw for applying the STELLA model, Frank Biasi,
Dan Morse and Barnaby Friedman for preparing GIS vegetation maps, Amanda Goebel and Barnaby Friedman for digitizing fire perimeters, John Borrow for drafting model figures, and Wei Fang, Eve Kaplan and Phillip Rutkowski for gathering post-wildfire field data. Bill Patterson IV, Tom Dooley, Brian Kurtz, John Litvaitis and an anonymous reviewer provided helpful comments on drafts of the article. This work was funded in part by the Biodiversity Research Institute of New York, and the US Forest Service/ Dept. of the Interior Cooperative Agreement for Restoration of Fire-adapted Ecosystems.

\section{References}

Abrams, M.D., 1992. Fire and the development of oak forests. BioScience 42, 346-353.

Allen, D.Y., 1997. Long Island maps and their makers. Amereon House, Mattituck, NY, 153 pp.

Andresen, J.W., 1959. A study of pseudo-nanism in Pinus rigida Mill. Ecol. Monogr. 29, 309-332.

Backman, A.E., 1984. 1000-Year Record of Fire-Vegetation Interactions in the Northeastern United States: A Comparison Between Coastal and Inland Regions. M.S. Dissertation, Dept. of Forestry and Wildlife Management, University of Massachusetts, Amherst, MA.

CPBJPPC, 1995. Central Pine Barrens Comprehensive Land Use Plan, vol. 1-2. Central Pine Barrens Joint Planning and Policy Commission, P.O. Box 587, Great River, NY 11739-0287, USA, http://www.pb.state.ny.us/.

Cryan, J.F., 1981. Major vegetation of Long Island. Heath Hen 1 (2-3), 41.

Cryan, J.F., Turner, J.L., 1981. A landscape imperiled: the Long Island oak brush plains. Heath Hen 1 (2-3), 3-34.

Dunwiddie, P.W., Patterson III, W.A., Rudnicky, J.L., Zaremba, R.E., 1997. Vegetation management in coastal grasslands on Nantucket Island, Massachusetts: effects of burning and mowing from 1982-1993. In: Vickery, P.D., Dunwiddie, P.W. (Eds.), Grasslands of Northeastern North America: Ecology and Conservation of Native and Agricultural Landscapes. Massachusetts Audubon Society, Lincoln, MA, pp. 85-98.

Dwight, T., 1821. Travels in New England and New York, Part IV. In: Solomon, B.M. (Ed.), Cambridge, Massachusetts, 1969, p. 186 (As quoted by Cronon, W., 1983. Changes in the Land: Indians, Colonists, and the Ecology of New England. Hill and Wang, New York).

Elias, T.S., 1987. The complete trees of North America, field guide and natural history. Gramercy Publishing Co., New York.

Finton, A.D., 1998. Succession and plant community development in pitch pine-scrub oak barrens of the glaciated northeast United States. M.S. Thesis, Univ. of Massachusetts, MA, 179 pp.

Forman, R.T., 1979. Pine Barrens: Ecosystem and Landscape. Academic Press, New York. 601 pp. 
Fowells, H.A. (Ed.), 1965. Silvics of Forest Trees of the United States. Agriculture Handbook No. 271, US Dept. Agriculture, Forest Service, Washington, DC, p. 762.

Gibson, D.J., Zampella, R.A., Windisch A.G., 1999. New Jersey Pine Plains: the "true barrens" of the New Jersey pine barrens. In: Anderson, R.C., Fralish, J.S., Baskin, J.M. (Eds.), Savannas, Barrens and Rock Outcrop Plant Communities of North America. Cambridge University Press, New York, pp. 52-66.

Givnish, T.J., 1981. Serotiny, geography and fire in the pine barrens of New Jersey. Evolution 35, 101-123.

Good, R.E., Good, N.F., 1975. Growth characteristics of two populations of Pinus rigida from the pine barrens of New Jersey. Ecology 56, 1215-1220.

Haines, D.A., 1982. Horizontal roll vortices and crown fires. J. Appl. Meterol. 21, 751-763.

Harper, R.M., 1912. The Hempstead Plains of Long Island. Torreya 12, 277-287.

Hicks, H., 1892. The Flora of the Hempstead Plains, Long Island. B.S. Dissertation, Cornell University, Ithaca, NY. p. 26.

Horn, H.S., 1975. Markovian properties of forest succession. In: Cody, M.L., Diamond, J.M. (Eds.), Ecology and Evolution of Communities. Belknap Press of Harvard University Press, Cambridge, MA, pp. 196-211.

Horn, H.S., 1981. Succession. In: May, R.M. (Ed.), Theoretical Ecology: Principles and Applications. Sinauer Associates, Sunderland, MA, pp. 253-271.

Kurczewski, F.E., Boyle, J.F., 2000. Historical changes in the pine barrens of central Suffolk County, New York. Northeast. Natural. 7, 95-112.

Ledig, F.T., Little, T., 1979. Pitch pine (Pinus rigida Mill.): ecology, physiology and genetics. In: Forman, R.T.T. (Ed.), Pine Barrens: Ecosystem and Landscape. Academic Press, NY, pp. 347-371.

Little, S., Silvical characteristics of pitch pine (Pinus rigida). US Dept. Agriculture, Forest Service Northeastern Forest Experiment Station. Station Paper 119, pp. 1-22.

Little, S., 1979. Fire and plant succession in the New Jersey Pine Barrens, In: Forman, R.T.T. (Ed.), Pine Barrens: Ecosystem and Landscape. Academic Press, NY, pp. 297-314.

Little, S., Somes, H.A., 1956. Buds enable pitch and shortleaf pines to recover from injury. US Dept. Agriculture, Forest Service Northeastern Forest Experiment Station. Station Paper \#81, 14 pp.

Little, S., Somes, H.A., 1964. Releasing pitch pine sprouts from old stools ineffective. J. Forestry 62, 23-26.

Little, S., Moorhead, G.R., Somes, H.A., 1958. Forestry and deer in the pine region of New Jersey. US Dept. Agriculture, Forest Service Northeastern Forest Experiment Station. Station Paper 109, 1-33.

Motzkin, G., Foster, D.R., 2002. Grasslands, heathlands and shrublands in coastal New England: historical interpretations and approaches to conservation. J. Biogeogr. 29, 1569-1590.

Motzkin, G., Foster, D.R., Allen, A., Harrod, J., Boone, R., 1996. Controlling site to evaluate history: vegetation patterns of a New England sand plain. Ecol. Monogr. 66, 345-365.

Motzkin, G., Ciccarello, S., Foster, D.R., 2002. Frost pockets on a level sand plain: does variation in microclimate help maintain persistent vegetation patterns? J. Torrey Bot. Soc. 129, 154-163.
McNamara, E.F., 1960. Sprouting capacity of scrub oak. J. Forestry $58,563-564$.

NatureServe, 2003. International Classification of Ecological Communities: Terrestrial Vegetation of the United States, Northeastern Subset. Report from the Biological Conservation Datasystem, February 2003. NatureServe, Arlington, VA/ Boston, MA. http://www.natureserve.org/publications/library.jsp.

Noble, I.R., Slatyer, R.O., 1977. Post-fire succession of plants in Mediterranean ecosystems. In: Mooney, H.A., Conrad, C.E. (Technical coordinators), Proceedings of the Symposium on the Environmental Consequences of Fire and Fuel Management in Mediterranean Ecosystems, Palo Alto, CA, 1-5 August 1977. USDA Forest Service General Technical Report WO-3, Washington, DC, pp. 27-36.

Noss, R.F., LaRoe III, E.T., Scott, J.M., 1995. Endangered Ecosystems of the United States: A Preliminary Assessment of Loss and Degradation. Biological Report 28. US Dept. of the Interior, National Biological Service, Washington, DC, 20240.

New York Natural Heritage Program (NYNHP), 2002a. Rare Animal List. 625 Broadway, 5th Floor, Albany, NY 122334757, USA. http://www.dec.state.ny.us/website/dfwmr/heritage/.

New York Natural Heritage Program (NYNHP), 2002b. Draft Ecological Communities of New York State. 625 Broadway, 5th Floor, Albany, NY 12233-4757. http://www.dec.state.ny.us/ website/dfwmr/heritage/Draft_ECNY2002.htm (a revised and expanded edition of Reschke, 1990).

Patterson III, W.A., Sassaman, K.E., 1988. Indian fires in the prehistory of New England. In: Nicholas, G. (Ed.), Holocene Human Ecology in Northeastern North America. Plenum, New York, pp. 107-135.

Peterson, S., Richmond, B., 1994. STELLA II, Technical documentation. High Performance Systems, Lebanon, NH 03766. http://www.hps-inc.com/STELLAVPSR.htm.

Reiners, W.A., 1965. Ecology of a heath-shrub synusia in the pine barrens of Long Island, New York. Bull. Torrey Bot. Club 92, 448-464.

Roth, E.R., Hepting, G.H., 1943. Origin and development of oak stump sprouts as affecting their likelihood to decay. J. Forestry $41,27-36$.

Rowe, J.S., 1983. Concepts of fire effects on plant individuals and species. In: Wein, R.W., MacLean, D.A. (Eds.), The Role of Fire in Northern Circumpolar Ecosystems. Wiley, New York, pp. 135-154.

Schweitzer, D.F., Rawinski, T.J., 1988. Element Stewardship Abstract for Northeastern Pitch Pines-Scrub Oak Barrens. The Nature Conservancy, Arlington, VA, 22 pp.

Town of Southampton, 1993. Western Town Generic Environmental Impact Study: The Comprehensive Plan Initiative for Groundwater Protection and Pine Barrens Forest Preservation. Part I: Surveys and Analyses. Southampton Town Dept. of Planning and Natural Resources. Southampton, NY 11968 (pp. not available).

Stevens, A., 1996. The paleoecology of coastal sandplain grasslands on Martha's Vineyard, Massachusetts. Ph.D. Dissertation, University of Massachusetts, Amherst, MA. 
Thompson, J.E., 1995. Interrelationships Among Vegetation Dynamics, Fire, Surficial Geology, and Topography of the Southern Pocono Plateau, Monroe County, Pennsulvania. M.S. Thesis, University of Pennsylvania, 159 pp.

Tredwell, D.M., 1912. Personal Reminiscences of Man and Things on Long Island. Charles Ditmas, Brooklyn, NY.

Unnasch, R.S., 1990. Seed predation and limits to recruitment in two species of Pine Barrens oak. Ph.D. Thesis, State University of New York, Stony Brook.

USDA-SCS, 1975. Soil Survey of Suffolk County, New York. US Dept. of Agriculture, Soil Conservation Service in Cooperation with Cornell Agricultural Experiment Station. Riverhead County Center, Riverhead, NY 11901.
Wagner, D.L., Nelson, M.W., Schweitzer, D.F., 2003. Shrubland Lepidoptera of southern New England and southeastern New York: ecology, conservation, and management. For. Ecol. Manage. (this issue).

Windisch, A.G., 1999. Fire Ecology of the New Jersey Pine Plains and Vicinity. Ph.D. Dissertation, Rutgers-The State University, New Brunswick, NJ, 327 pp.

Wolgast, L.J., 1972. Mast production in scrub oak on the coastal plain in New Jersey. Ph.D. Dissertation, Rutgers University, New Brunswick, NJ.

Wolgast, L.J., Stout, B.B., 1977. Effects of age, stand density, and fertilizer application on bear oak reproduction. J. Wildlife Manage. 41, 685-691. 